\title{
スポーツに起因する顎顔面骨骨折の臨床統計
}

\author{
田中信幸・君島裕・佐藤美樹 \\ 塩谷健一.天笠光雄
}

\section{Clinicostatistical observation of sports-related maxillofacial fractures}

\author{
Nobuyuki Tanaka $\cdot$ Yutaka Kimisima $\cdot$ Miki Sato \\ Kenichi Shionoya $\cdot$ Teruo Amagasa
}

\begin{abstract}
We performed a clinicostatistical study of 102 maxillofacial fractures due to sports during the 17-year period between 1977 and 1993 at The First Department of Oral and Maxillofacial Surgery, Faculty of Dentistry, Tokyo Medical and Dental University, Japan. Of all maxillofacial fractures, the rate of sports-related fractures was $10.5 \%$. The patients had injuries resulting from 22 different sports, and the most common sport responsible for injury was rugby, followed by skiing, baseball, and soccer. The ratio of males to females was $6: 1$, and the majority of the patients were between 10 and 29 years old. Fractures of the mandible and the alveolar process were common. Conservative therapy, such as maxillomandibular fixation, was usually performed.
\end{abstract}

Key words: maxillofacial fracture (顎顔面骨骨折), sports (スポーツ), rugby（ラグビー）

\begin{abstract}
緒言
近年, 本邦ではスポーツの普及に伴い, スポーツと 生体との関連について各種の研究がなされ,「スポー ツ医学」という分野が確立された ${ }^{1)}$.ささらに，スポー ッと咬合をはじめとする歯科領域との関連についての 研究もなされ,「スポーツ歯学」も確立されつつあ $ろ^{2)}$. 口腔外科領域では, スポーツに起因する外傷症 例を治療する機会が多く，今回われわれはスポーツ外 傷による顎顔面骨骨折について検討し，若干の知見が 得られたので報告する。
\end{abstract}

\section{対象症例および研究方法}

1977 年から 1993 年までの 17 年間に当科を受診した スポーツによる顎顔面骨骨折症例 102 例を対象とし, 受傷原因, 年齢, 性別, 骨折発生部位, 治療法につい て検索した。

\section{東京医科歯科大学歯学部口腔外科学第一講座}

(主任 : 天笠光雄教授)

The First Department of Oral and Maxillofacial Surgery, Faculty of Dentistry, Tokyo Medical and Dental University (Chief: Prof. Teruo Amagasa)

受付日: 平成 7 年 6 月 29 日

\section{結果 \\ 1. 受賃原因と年齢・性別}

受傷原因となったスポーツは 22 種類におよび，ラ グビーが 24 例, $23.5 \%$ を占め, 最も多く, 続いてスキー が 23 例, 野球が 13 例, サッカーが 11 例であった.

年齢別では, 最年少が 8 歳, 最年長が 48 歳であり, 20 歳代が 54 例, $52.9 \%$ を占め, 続いて 10 歳代が 35 例, $34.3 \%$ を占めた（表 1 )。男女別では，男 87 例，女 15 例で, 男女比は $6: 1$ であった. 女性の症例をスポー ツ別にみると, スキーが 6 例, ソフトボールが 3 例, ゴルフが 2 例, バレーボール, レスリング, ウエイト トレーニングがそれぞれ 1例であった.

おのおののスポーツにおける受傷の直接原因として は,プレーヤー同志の衝突が 59 例 (57.8\%) にみられ, 次いでボールやスキー板などのスポーツ器具との接触 によるものが 26 例 (25.5\%) であった。 その他, 地面 や床に転倒しての骨折が 10 例みられた。

\section{2. 骨折部位}

骨折部位は下顎骨骨体（下顎歯槽部を除く）単独が 60 例 $(58.8 \%)$ を占め, 最も多く, 次いで歯槽部（上 顎歯槽突起, 下顎歯槽部) であった. 少数ではあるが, 上顎骨折，上下顎に及ぶ複数骨の骨折，煩骨煩骨弓骨 
表 1 受傷原因のスポーツと年齢分布

\begin{tabular}{|c|c|c|c|c|c|c|}
\hline \multirow[t]{2}{*}{ スポーツ } & \multicolumn{5}{|c|}{ 年 齢 } & \multirow[b]{2}{*}{ 合計 } \\
\hline & $0-$ & $10-$ & $20-$ & $30-$ & $40-$ & \\
\hline ラグビー & - & 10 & 14 & - & - & 24 \\
\hline スキー & 1 & 3 & 14 & 2 & 3 & 23 \\
\hline 野球 & - & 7 & 5 & 1 & - & 13 \\
\hline サッカー & - & 6 & 3 & 1 & 1 & 11 \\
\hline ゴルフ & - & - & 1 & 1 & 1 & 3 \\
\hline ソフトボール & - & 3 & - & - & - & 3 \\
\hline 空手 ～ & - & - & 3 & - & - & 3 \\
\hline 柔道 & - & 2 & 1 & - & - & 3 \\
\hline 少林寺拳法 & - & - & 1 & - & - & 1 \\
\hline 射道 & - & - & 1 & - & - & 1 \\
\hline ボクシング & - & - & 2 & - & - & 2 \\
\hline バレーボール & - & - & 1 & 1 & - & 2 \\
\hline 相撲 & - & - & 1 & - & - & 1 \\
\hline 競輪 & - & - & - & 1 & - & 1 \\
\hline レスリング & - & - & 3 & - & - & 3 \\
\hline テニス & - & - & 1 & - & - & 1 \\
\hline アイスホッケー & - & - & 1 & - & - & 1 \\
\hline ジェットスキー & - & - & 1 & - & - & 1 \\
\hline バスケットボール & - & 1 & - & - & - & 1 \\
\hline ハンドボール & - & 1 & - & - & - & 1 \\
\hline ウエイトトレイニング & - & 1 & - & - & - & 1 \\
\hline サーフィン & - & - & 1 & - & - & 1 \\
\hline 不明 & - & 1 & - & - & - & 1 \\
\hline 合計 & 1 & 35 & 54 & 7 & 5 & 102 \\
\hline$\%$ & 1.0 & 34.3 & 52.9 & 6.9 & 4.9 & 100 \\
\hline
\end{tabular}

折がみられた（表 2 ).

\section{3 . 治療法}

102 例中 90 例に非観血的処置がなされ，その内 50 例に顎間固定が施された。顎内固定が 13 例に施され, その他チンキャップによる顎外固定や抜歯を含めた消 炎療法が行われた. 顎間固定は $4 \sim 6$ 週間行われた.

\section{考察}

近年, 本邦ではスポーツの普及に従い, スポーツに関 連した歯学研究も散見されるようになっている2 4) が, 顎顔面領域のスポーツに起因する骨折についての 研究は比較的少ない5). 今回, 17 年間に当科で経験し たスポーツ外傷による骨折症例は 102 例であり, 全顎 顔面骨骨折症例の約 10\%を占めていた. 顎顔面骨骨折 の原因については地域や時代的背景などにより左右さ れやすく, スポーツ外傷の数もその地域のスポーツの 普及度と関連し, 今後の増加が考えられる。 今回の検 索においてはラグビー, スキー, 野球, サッカーがそ
の原因として多くみられたが，イギリスの Hill ら ${ }^{6)}$ はラグビー, クリケット, サッカーが, イタリアの Frenquill ら 7) はサッカーが多かったと報告している. 本邦においては, スキーの接触事故による骨折が多い のが特徴である. 年齢・性別分布については, 20 歳代 の男性に多くみられたが,これは原因となったスポー ツをする者がこの年代の男性に多いためと思われる.

各種スポーツについて, 骨折の起こしやすい部位, 骨折の直接の原因を検索し, おのおののスポーツに対 して予防策を講じることは有効である. 今回の検索で はおのおののスポーツに特異的にみられる骨折部位は 見出し難かった。骨折の多くはプレーヤー同志の衝突 によるものであり,これに対してアメリカンフットボー ルやラグビーではマウスガードの使用により骨折があ る程度防ぎ得るとされている8 10).

\section{結語}

1977 年から 1993 年までの 17 年間に当科を受診した 
表 2 スポーツによる骨折部位

\begin{tabular}{|c|c|c|c|c|c|c|c|c|}
\hline スポーツ & 複数骨 & 下顎骨 & 上顎骨 & 煩骨 & 歯槽部 & 鼻骨 & 不明 & 合計 \\
\hline ラグビー & 上顎骨＋下顎骨 4 & 15 & 2 & - & 2 & 1 & & 24 \\
\hline スキー & - & 14 & 2 & 1 & 6 & - & & 23 \\
\hline 野球 & - & 8 & 1 & 1 & 3 & - & & 13 \\
\hline サッカー & 上顎骨＋下顎骨 2 & 5 & 1 & - & 3 & - & & 11 \\
\hline ゴルフ & - & - & - & - & 3 & - & & 3 \\
\hline ソフトボール & 下顎骨＋歯槽部 (上) 1 & 2 & - & - & - & - & & 3 \\
\hline 空手 & - & 3 & - & - & - & - & & 3 \\
\hline 柔道 & - & 3 & - & - & - & - & & 3 \\
\hline 少林寺拳法 & - & - & - & 1 & - & - & & 1 \\
\hline 躱道 & - & - & - & - & - & 1 & & 1 \\
\hline ボクシング & - & 2 & - & - & - & - & & 2 \\
\hline バレーボール & - & 1 & - & - & 1 & - & & 2 \\
\hline 相撲 & - & 1 & - & - & - & - & & 1 \\
\hline 競輪 & - & 1 & - & - & - & - & & 1 \\
\hline レスリング & - & 2 & - & - & - & - & 1 & 3 \\
\hline テニス & - & - & - & - & 1 & - & & 1 \\
\hline アイスホッケー & - & - & - & 1 & - & - & & 1 \\
\hline ジェットスキー & - & 1 & - & - & - & - & & 1 \\
\hline バスケットボール & - & - & - & - & 1 & - & & 1 \\
\hline ハンドボール & - & 1 & - & - & - & - & & 1 \\
\hline ウエイトトレイニング & - & - & - & - & 1 & - & & 1 \\
\hline サーフィン & - & 1 & - & - & - & - & & 1 \\
\hline 不明 & - & - & - & - & 1 & - & & 1 \\
\hline $\begin{array}{l}\text { 合 }{ }^{\text {計 }}(\%) \\
\end{array}$ & $\begin{array}{c}7 \\
(6.9)\end{array}$ & $\begin{array}{c}60 \\
(58.8)\end{array}$ & $\begin{array}{c}6 \\
(5.9)\end{array}$ & $\begin{array}{c}4 \\
(3.9)\end{array}$ & $\begin{array}{c}22 \\
(21.6)\end{array}$ & $\begin{array}{c}2 \\
(1.9)\end{array}$ & $\begin{array}{c}1 \\
(1.0)\end{array}$ & $\begin{array}{c}102 \\
(100)\end{array}$ \\
\hline
\end{tabular}

スポーツに起因した顎顔面骨骨折症例 102 例について 臨床統計的に検討した. 原因別ではラグビー, スキー, 野球, サッカーが多く, 部位別では下顎骨, 歯槽部 （上顎歯槽突起, 下顎歯槽部）が多く, 保存的療法が大 半になされていた。

本論文の要旨は, 第 48 回日本口腔科学会総会 (平成 6 年 4 月曰日, 別府市) において発表した。

\section{引用文 献}

1) 黒田善雄 : スポーツ医学序論. 中嶋寞之編, ス ポーツ外傷と障害, 1983, 文光堂, 東京, 1-6 頁.

2）石島 勉 : スポーツデンテイストの役割. 日本 歯科医師会誌 43: 1249-1262 1991.

3）大山喬史 : スポーツ歯学の現状と展望 (その 1$)$. 口病誌 59: 607-612 1992.

4) 大山喬史 : スポーツ歯学の現状と展望 (その 2 ). 口病誌 60: 257-263 1993.

5）沢木佳弘, 成瀬文和，他：スポーツ外傷による
顎顔面骨折に関する研究． 口科誌 39: 557-566 1990.

6) Hill, C.M., Crosher, R.F., et al.: Dental and facial injuries following sports accidents: A study of 130 cases. Br J Oral Maxillofac Surg 23: 268-274 1985.

7) Frenguelli, A., Ruscito, P., et al.: Head and neck trauma in sporting activities. $J$ Cranio-Max-Fac Surg 19: 178-191 1991.

8) Garon, M.W., Merkle, A., et al.: Mouth protectors and oral trauma: a study of adolescent football players. JADA 112: 663-665 1986.

9) Tompson, B.D.: Protection of the head and neck. Dental Clinics of North America 26: 659-667 1982.

10）石島 勉, 斎藤 実, 他：口腔領域のスポーツ 外傷とマウスガードに関する調査. 愛院大歯誌 27: 673-686 1988. 